\title{
Responses of three freshwater planktonic ciliates with different feeding modes to cryptophyte and diatom prey
}

\author{
Helga Müller*, Anja Schlegel \\ Limnological Institute, University of Konstanz, PO Box 5560, D-78434 Konstanz, Germany
}

\begin{abstract}
The filter feeding oligotrich ciliate Strobilidium lacustris, the raptorial prostome ciliate Balanion planctonicum and the diffusion feeding scuticociliate Histiobalantium bodamicum could be cultivated for months/years on a sole diet of Cryptomonas sp., whereas the diatom Stephanodiscus hantzschii did not support their growth. With Cryptomonas sp. as food, numerical responses of all ciliates followed a modified Michaelis-Menten model, which at $15^{\circ} \mathrm{C}$ yielded maximum growth rates of $0.96,1.87$ and $0.33 \mathrm{~d}^{-1}$ and threshold concentrations of 61,78 and $290 \mathrm{ng} \mathrm{C} \mathrm{ml}^{-1}$ for S. lacustris, B. planctonicum and $H$. bodamicum, respectively. Functional response patterns differed between species. In all investigated ciliates, growth rates reached a maximum earlier than ingestion rates, and there were no threshold concentrations for zero ingestion. Food selectivity depended on feeding mode. H. bodamicum was not able to ingest the non-motile diatoms. Both $S$. lacustris and $B$. planctonicum selectively preferred cryptophytes when offered a mixed diet. This effect was more pronounced in the raptorial feeder compared to the filter feeder. Our results indicate that during the phytoplankton spring bloom in Lake Constance prostome and oligotrich ciliates mainly exploit cryptophytes, and that the scuticociliate $H$. bodamicum, due to its slow growth, is an inferior competitor during this season. The observed threshold concentrations suggest that during the rest of the year prostomes and oligotrichs must rely on small-scale patches of this food, whereas $H$. bodamicum, with maximum development in late summer and autumn, presumably consumes a much larger variety of prey
\end{abstract}

KEY WORDS: Ciliate - Numerical response - Functional response - Feeding mode - Selective feeding Cryptophyte $\cdot$ Diatom - Balanion $\cdot$ Strobilidium $\cdot$ Histiobalantium

\section{INTRODUCTION}

Ciliate grazing on phytoplankton is a significant pathway of carbon flow in marine and freshwater pelagic food webs (Sherr \& Sherr 1994, Finlay \& Fenchel 1996). Since ciliate growth and grazing rates largely depend on the quantity and quality of available food, and since these responses are species specific, investigations on a large variety of predator-prey relationships are needed for a better understanding of this important trophic relationship. Available literature data mainly refer to filter feeding marine oligotrich ciliates, while data concerning freshwater species and ciliates with other feeding modes are scarce (for reviews see Montagnes 1996, Hansen et al. 1997).

•E-mail: helga.mueller@uni-konstanz.de
For the present study, we selected 3 ciliate species from Lake Constance, Germany, which represent the 3 basic feeding modes known in suspension feeding protozod (Fenchel 1987). These were the oligotrich ciliate Strobilidium lacustris, a filter feeder, the prostome ciliate Balanion planctonicum, a raptorial feeder, and the scuticociliate Histiobalantium bodamicum, a diffusion feeder (Müller \& Weisse 1994). We investigated their numerical and functional responses to a wide range of concentrations of Cryptomonas sp. and studied their selective behaviour when Cryptomonas sp. and the diatom Stephanodiscus hantzschii were offered simultaneously.

The phytoplankton spring bloom in Lake Constance is dominated by the cryptophytes Rhodomonas spp. and Cryptomonas spp. and the small centric diatom Stephanodiscus hantzschii (Weisse et al. 1990, Küm- 
merlin 1991, Sommer et al. 1993). Balanion planctonicum and Strobilidium lacustris are conspicuous members of the ciliate community during this season. A small population of Histiobalantium bodamicum is also regularly observed in spring, though maximum development of this ciliate occurs in late summer and autumn (Müller et al. 1991, Müller \& Weisse 1994). The ciliates and algae studied in the present in vitro experiments, therefore, represent potential predator-prey relationships in this lake. Our results are discussed in the context of previous field investigations in Lake Constance.

\section{MATERIALS AND METHODS}

Stock cultures. Cryptomonas sp, strain 26.80 from the algal culture collection in Göttingen (formerly called Rhodomonas sp., strain 26.80): this strain has been frequently used in grazing experiments at the Limnological Institute (e.g. Giani 1991, Müller 1991, Müller \& Geller 1993, Müller \& Weisse 1994). Weisse \& Kirchhoff (1997) measured a mean cell volume of 280 $\mu \mathrm{m}^{3}$. Stock cultures were grown at $15^{\circ} \mathrm{C}$ in Medium WC (Guillard \& Lorenzen 1972). The cultures were illuminated with fluorescent light on a $12: 12 \mathrm{~h}$ light:dark cycle at an irradiance of $\sim 60 \mu \mathrm{E} \mathrm{m} \mathrm{m}^{-2} \mathrm{~s}^{-1}$.

Stephanodiscus hantzschii: This species was isolated from surface waters of Lake Constance and has a mean cell volume of $133 \mu^{3}$ (Giani 1991). Stock cultures were maintained under the same conditions as the Cryptomonas sp. cultures.

Balanion planctonicum (formerly Pseudobalanion planctonicum) (Foissner et al., 1990) Foissner et al., 1994. The strain used in the present study was started from a multiclonal isolate obtained from surface waters of Lake Constance in April 1993. Stock cultures were grown in sterile filtered lake water at $9^{\circ} \mathrm{C}$ on a $12: 12 \mathrm{~h}$ light:dark cycle with Cryptomonas sp. as food. According to Müller \& Geller (1993), the species has a mean live cell volume of $\sim 1800 \mu^{3}$.

Strobilidium lacustris Foissner et al., 1988: this species was placed in the genus Rimostrombidium Jankowski, 1978, by Petz \& Foissner (1992). However, since the validity of this genus is controversially debated (see Montagnes \& Taylor 1994), and since Foissner (1994) stated that 'Rimostrombidium is an unfortunate name', we will use the traditional generic name Strobilidium throughout this text. According to Müller \& Geller (1993), the species has a live cell volume of $\sim 113000 \mu^{3}$. The strain used in the present study was started from a multiclonal isolate obtained from surface waters of Lake Constance in April 1995. Maintenance of stock cultures was the same as with Balanion planctonicum.
Histiobalantium bodamicum Krainer \& Müller, 1995: This species is identical to Histiobalantium sp. studied by Müller \& Weisse (1994), who determined a live cell volume of $-34000 \mu \mathrm{m}^{3}$. The strain used in the present study was started from a multiclonal isolate obtained from surface waters of Lake Constance in November 1996. Stock cultures were grown in 'Volvic', a commercial mineral water from the Auvergne, France, which has been traditionally used as a culture medium for ciliates (e.g. Dragesco \& Iftode 1972). Food, temperature and light conditions were the same as with Balanion planctonicum and Strobilidium lacustris.

For brevity, these strains will be referred to as Cryptomonas, Stephanodiscus, Balanion, Strobilidium and Histiobalantium throughout the 'Materials and methods' and 'Results' sections. All cultures contained bacteria. Small heterotrophic flagellates $<5 \mu \mathrm{m}$ were also present in the Balanion and Histiobalantium cuitures. In accordance with previous observations, these organisms were not considered to be a food source for the ciliates under investigation (cf. Müller 1991, Müller $\&$ Weisse 1994).

Experimental cultures with Cryptomonas. All experiments were performed in batch cultures. Ciliate stock cultures were adapted to $15^{\circ} \mathrm{C}$ at least $2 \mathrm{~d}$ prior to the experiments. $100 \mathrm{ml}$ culture bottles filled with $80 \mathrm{ml}$ of sterile filtered lake water (for Balanion and Strobilidium) or Volvic (for Histiobalantium) were inoculated with different concentrations of Cryptomonas and 1 ciliate species. Initial Cryptomonas concentrations ranged from 18 to $98 \times 10^{3}$ cells $\mathrm{ml}^{-1}$, initial ciliate concentrations were $\sim 24 \mathrm{Bal}$ anion $\mathrm{ml}^{-1}, 3$ to 10 Strobilidium $\mathrm{ml}^{-1}$ and -80 Histiobalantium $\mathrm{ml}^{-1}$. Control bottles received only Cryptomonas at a similar range of concentrations to the experimental bottles. After inoculation, all bottles were exposed to $15^{\circ} \mathrm{C}$ and dim light $(12: 12 \mathrm{~h}$ light:dark cycle, $\sim 10 \mu \mathrm{E} \mathrm{m} \mathrm{m}^{-2} \mathrm{~s}^{-1}$ ). Exact cell numbers were first determined $24 \mathrm{~h}$ after inoculation, to allow for recovery of the ciliates from handling stress and for adaptation to the experimental food concentration. Subsequently, changes in cell numbers were recorded at intervals of 12,24 and $48 \mathrm{~h}$ in the Balanion. Strobilidium and Histiobalantium experiments respectively. Experimental time was 2 to $3 \mathrm{~d}$ with Balanion, 3 to $5 \mathrm{~d}$ with Strobilidium and 6 to $10 \mathrm{~d}$ with Histiobalantium. For enumeration of algae and ciliates, $5 \mathrm{ml}$ samples were taken from the cultures after gentle mixing. These, after fixation with acid Lugol's solution, served for counting of algae and ciliates in Sedgewick-Rafter chambers. Three entire chambers, i.e. $3 \mathrm{ml}$ of sample volume, were scanned for the ciliates. At least 200 Cryptomonas cells were counted per sample, except at the end of experi- 
ments, when algae had been reduced to very low concentrations.

With Strobilidium, we aiso tested a semi-continuous culturing technique according to Montagnes (1996). However, micropipette transfers required for this method caused dramatic mortality within $24 \mathrm{~h}$ compared to undisturbed control specimens, though the ciliates appeared undamaged shortly after the transfers. Similar attempts with the even more fragile Histiobalantium and the small Balanion were also unsuccessful.

Experimental cultures with Cryptomonas and Stephanodiscus. The ability of the ciliates to ingest Stephanodiscus was tested by the following procedure: batch cultures of Balanion, Strobilidium and Histiobalantium, in which most of the Cryptomonas food had been depleted, were incubated with a high concentration of Stephanodiscus for $2 \mathrm{~h}$. Though sedimentation of Stephanodiscus in the culture dishes was not prevented, 3 to $10 \times 10^{4}$ diatoms $\mathrm{ml}^{-1}$ were in suspension over the incubation period. Subsequently, the ciliates were checked for ingested diatoms, either by live observation or after fixation with $\mathrm{HgCl}_{2}$ (0.06\% final concentration) and staining with protargol according to the protocol of Foissner (1991).

Selective feeding experiments with Balanion and Strobilidium were performed in $500 \mathrm{ml}$ culture bottles containing $200 \mathrm{ml}$ of sterile filtered lake water. Ciliate stock cultures for these experiments had been maintained at $15^{\circ} \mathrm{C}$ for at least $2 \mathrm{wk}$. Experimental bottles (a) were inoculated with Cryptomonas, Stephanodiscus and 1 ciliate culture. Initial cell concentrations were 2 to $5 \times 10^{4}$ cryptophytes $\mathrm{ml}^{-1}, 2$ to $4 \times 10^{4}$ diatoms $\mathrm{ml}^{-1}, 20$ to 30 Balanion $\mathrm{ml}^{-1}$ and 15 to 30 Strobilidium $\mathrm{ml}^{-1}$. Control bottles received: ciliates + Cryptomonas (control bj, Stephanodiscus + Cryptomonas (control c) or only Cryptomonas (control d) at similar concentrations. To prevent sedimentation of the diatoms, all bottles were placed in an overhead mixer (REAX $20 / 8$ from Heidolph, Germany) which rotated for $3 \mathrm{~min}$ ( $1 \mathrm{rpm}$ ) every $2 \mathrm{~h}$. Each experiment consisted of 8 culture bottles, which was the capacity of the overhead mixer. These were either 2 replicates each of experimental bottles (a) and control bottles (b, $c$, and $d$ ), or 3 replicates each of bottles (a) and (b), 1 control (c) and 1 control (d). Temperature was $15^{\circ} \mathrm{C}$ and irradiation was $<3 \mu \mathrm{E} \mathrm{m}^{-2} \mathrm{~s}^{-1}$. Numbers of algae and ciliates were first determined $\sim 18 \mathrm{~h}$ after inoculation. Subsequently, changes in cell concentrations were followed at $24 \mathrm{~h}$ intervals, using the same method as described above.

Four selective feeding experiments were run with Balanion (B1 to B4). Several attempts were made with Strobilidium, a species which is very sensitive to changes in the chemical composition of the culture medium and, therefore, frequently does not survive transfers from a dense culture to fresh medium. Here we present data from 1 experiment (S1) in which the ciliates survived in all replicates, and from 2 experiments (S2 and S3) in which the ciliates survived in all replicates of bottles (a), but not in controls (b).

Data analysis. Growth, grazing loss, ingestion and clearance rates were calculated separately for each sampling interval of each culture according to Heinbokel (1978)

$$
\begin{aligned}
\mu & =\left(\ln N_{t}-\ln N_{0}\right) \times t^{-1} \\
N & =\left(N_{t}-N_{0}\right) \times\left(\ln N_{t}-\ln N_{0}\right)^{-1} \\
g & =\mu_{\text {control }}-\mu_{\text {experiment }} \\
I & =g \times N_{\text {prey }} \times\left(N_{\text {predator }} \times 24\right)^{-1} \\
F & =g \times 10^{6} \times\left(N_{\text {predator }} \times 24\right)^{-1}
\end{aligned}
$$

where $t=$ sampling interval $(\mathrm{d}) ; N_{0}$ and $N_{t}$ (cells $\mathrm{ml}^{-1}$ ) $=$ cell numbers at the beginning and end of $t ; N$ (cells $\mathrm{ml}^{-1}$ ) $=$ mean cell numbers within $t$, with the assumption of exponential increase or decrease of cells within each sampling interval; $\mu=$ growth rate $\left(\mathrm{d}^{-1}\right) ; g=$ grazing loss rates $\left(\mathrm{d}^{-1}\right) ; I=$ ingestion rate (prey cells $\times$ predator cells ${ }^{-1} \mathrm{~h}^{-1}$ ); and $F=$ clearance rate (nl predator cells ${ }^{-1} \mathrm{~h}^{-1}$ ).

Numerical response was analyzed by relating the resulting growth rates $(\mu)$ to the corresponding initial Cryptomonas cell numbers $N_{0}$ (see 'Discussion'). These data were fit to a modified Michaelis-Menten model, which has been frequently used to describe numerical responses of protozoa (e.g. Heinbokel 1978, Fenchel 1986, Montagnes 1996)

$$
\mu=\left[\mu_{\max } \times\left(N_{0}-k_{0}\right)\right] \times\left[k_{t}+\left(N_{0}-k_{0}\right)\right]^{-1}
$$

where $\mu_{\max }$ is the maximum growth rate, $k_{0}$ is the $x$ intercept or 'threshold concentration' (the food concentration where $\mu=0$ ) and $k_{0}+k_{t}$ is the 'half saturating concentration' (the food concentration at which $\mu=$ $\mu_{\max } / 2$ ). Curves were fit to the data using the Marquardt-Levenberg algorithm (Sigmaplot, Jandel Scientific, CA, USA).

Functional response was analyzed by relating the ingestion rates (I) obtained for each culture and sampling interval to the corresponding geometric mean Cryptomonas cell numbers $(N)$. These data were either fit to the Michaelis-Menten model

$$
I=\left(I_{\max } \times N\right) \times\left(k_{t}+N\right)^{-1}
$$

or described as a linear relationship

$$
I=a+N \times b
$$

where $I_{\max }$ is the maximum ingestion rate, $k_{t}$ is the half saturation concentration (the food concentration at which $I=I_{\max } / 2$ ), and $a$ and $b$ are constants. 

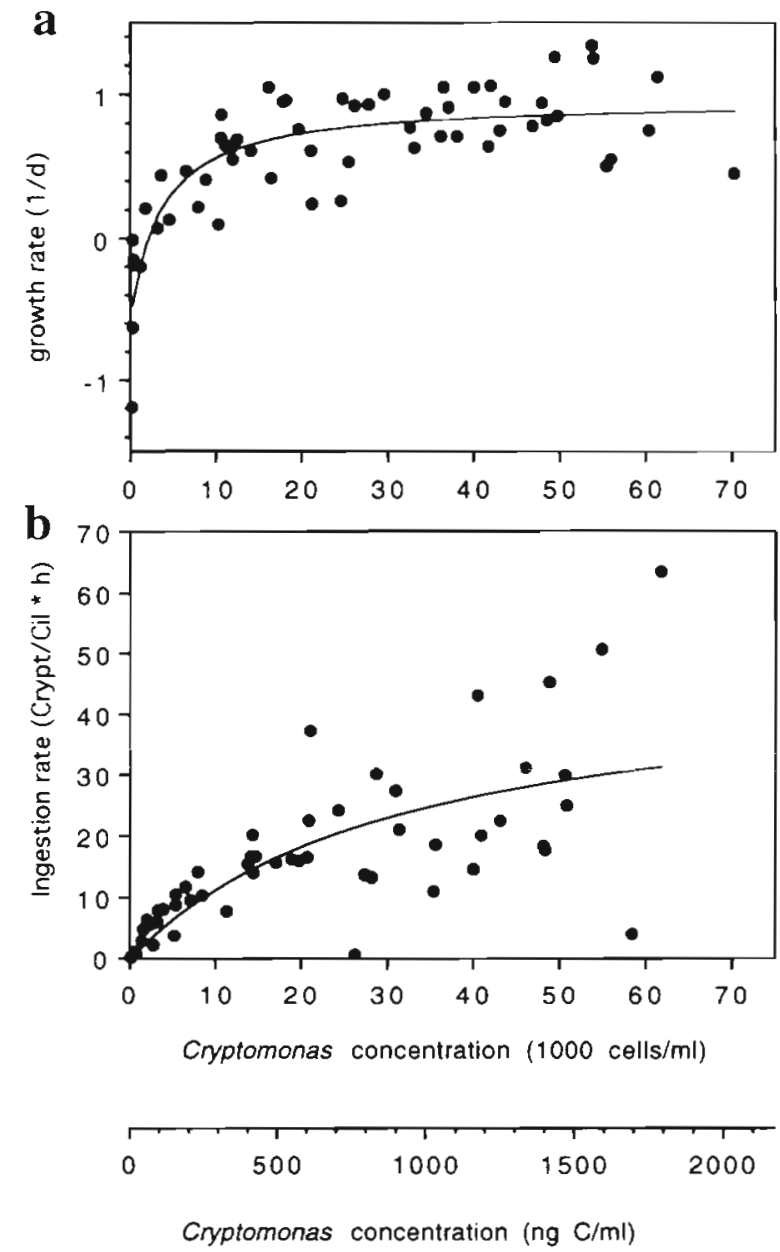

Fig. 1. Strobilidium lacustris. (a) Numerical response. Observed growth rates (1) and curve fit according to Eq. (6) (solid line). (b) Functional response. Observed ingestion rates (๑) and curve fit according to Eq. (7) (solid line)

Selectivity index $\left(D_{\mathrm{Cr}}\right)$ was calculated according to Jacobs (1974)

$$
D_{\mathrm{Cr}}=\left(F_{\mathrm{Cr}}-F_{\mathrm{St}}\right) \times\left(F_{\mathrm{Cr}}+F_{\mathrm{St}}\right)^{-1}
$$

where $F_{\mathrm{Cr}}$ is the clearance rate for Cryptomonas, $F_{\mathrm{St}}$ is the clearance rate for Stephanodiscus. $\mathrm{D}_{\mathrm{Cr}}$ may reach values between +1 (ingestion of Cryptomonas only) and -1 (ingestion of Stephanodiscus only). $D_{\mathrm{Cr}}=0$ indicates no selective ingestion.

Carbon concentrations of algal suspensions were estimated using the equation of Montagnes et al. (1994): $\mathrm{C}=0.109 \times V^{0.991}$, where $V=$ cell volume $\left(\mu \mathrm{m}^{3}\right)$ and $\mathrm{C}=$ carbon $\left(\mathrm{pg}\right.$ cell ${ }^{-1}$ ). For the mean cell volumes given above, this resulted in a carbon content of $29.0 \mathrm{pg} \mathrm{cell}^{-1}$ for Cryptomonas and of $13.9 \mathrm{pg} \mathrm{cell}^{-1}$ for Stephanodiscus.

Paired t-test (SigmaStat, Jandel Scientific, CA, USA) was applied to compare ciliate growth rates in different treatments of selective feeding experiments.

\section{RESULTS}

Numerical and functional response to Cryptomonas

\section{Controls}

Growth rates of Cryptomonas in control bottles with sterile filtered lake water ranged from 0.08 to $0.18 \mathrm{~d}^{-1}$. while in control bottles with Volvic, growth rates from 0.03 to $0.08 \mathrm{~d}^{-1}$ were observed. Therefore, a mean value of $\mu_{\text {control }}=0.12 \mathrm{~d}^{-1}$ was used in experiments with Balanion and Strobilidium and a mean value of $\mu_{\text {control }}$ $=0.05 \mathrm{~d}^{-1}$ in experiments with Histiobalantium to calculate grazing loss rates (Eq. 3).

\section{Strobilidium lacustris}

Growth and ingestion rates of Strobilidium relative to prey concentrations were fit to Michaelis-Menten Eqs. (6) \& (7), respectively, as illustrated in Fig. 1 and Tables $1 \& 2$. The half saturating concentration for ingestion was 4 -fold higher than that for growth. There was no threshold concentration for zero ingestion.

\section{Balanion planctonicum}

The growth response of Balanion (Fig. 2, Tables 1 \& 2) followed the modified Michaelis-Menten model.

Table 1. Growth parameters and estimates of error of numerical and functional response data (Figs. 1 to 3 ) fit to MichaelisMenten models (Eqs. 6 \& 7) using the SigmaPlot curve fitting program

\begin{tabular}{|c|c|c|c|}
\hline & Value & $\begin{array}{l}\text { Standard } \\
\text { error }\end{array}$ & $\begin{array}{c}\text { Coefficient) } \\
\text { of variance }(\%)\end{array}$ \\
\hline \multicolumn{4}{|c|}{ Strobilidium, numerical response } \\
\hline$\mu_{\max }\left(\mathrm{d}^{-1}\right)$ & 0.96 & 0.08 & 8 \\
\hline$k_{0}\left(\right.$ prey cells $\mathrm{ml}^{-1}$ ) & 2100 & 0.5 & 23 \\
\hline$k_{f}\left(\right.$ prey cells $\left.\mathrm{ml}^{-1}\right)$ & 5500 & 1.8 & 32 \\
\hline \multicolumn{4}{|c|}{ Strobilidium, functional response } \\
\hline $\begin{array}{l}I_{\max } \text { (prey cells } \\
\text { predator cells }{ }^{-1} \mathrm{~h}^{-1}\end{array}$ & 47.4 & 12.5 & 26 \\
\hline$k_{t}\left(\right.$ prey cells $\left.\mathrm{ml}^{-1}\right)$ & 31500 & 16.8 & 53 \\
\hline \multicolumn{4}{|c|}{ Balanion, numerical response } \\
\hline$\mu_{\max }\left(\mathrm{d}^{-1}\right)$ & 1.87 & 0.10 & 5 \\
\hline$k_{0}$ (prey cells $\mathrm{ml}^{-1}$ ) & 2700 & 0.4 & 15 \\
\hline$k_{t}\left(\right.$ prey cells $\left.\mathrm{ml}^{-1}\right)$ & 5400 & 1.1 & 21 \\
\hline \multicolumn{4}{|c|}{ Histiobalantium, numerical response } \\
\hline$\mu_{\max }\left(\mathrm{d}^{-1}\right)$ & 0.33 & 0.11 & 32 \\
\hline$k_{0}\left(\right.$ prey cells $\left.\mathrm{ml}^{-1}\right)$ & 10000 & 2.2 & 22 \\
\hline$k_{t}$ (prey cells $\left.\mathrm{ml}^{-1}\right)$ & 10200 & 4.0 & 40 \\
\hline
\end{tabular}


Table 2. Threshold concentrations (TC) and half saturating concentrations (HSC) of Balanion planctonicum, Strobilidium lacustris and Histiobalantium bodamicum in terms of carbon. These data were derived from Table 1, assuming a value of 29 pg C Cryptomonas cell ${ }^{-1}$

\begin{tabular}{|lcc|}
\hline & TC $\left(\mathrm{ng} \mathrm{C} \mathrm{ml}^{-1}\right)$ & HSC $\left(\mathrm{ng} \mathrm{C} \mathrm{ml}^{-1}\right)$ \\
\hline Strobilidium (growth) & 61 & 220 \\
Strobilidium (ingestion) & - & 913 \\
Balanion (growth) & 78 & 235 \\
Histiobalantium (growth) & 290 & 586 \\
\hline
\end{tabular}

While the maximum growth rate of the small Balanion was twice as high as that of Strobilidium, the threshold and half saturating concentrations of both species were not significantly different.

The ingestion rates of Balanion continuously increased over a range of prey concentrations from 0.1 to $82 \times 10^{3}$ Cryptomonas cells $\mathrm{ml}^{-1}$ (Fig. 2). At higher food levels, a decline of ingestion rates was observed. Attempts to fit these data to Eq. (7) (dotted line in Fig. 2) resulted in a maximum ingestion rate of 18 Cryptomonas cells ciliate ${ }^{-1} \mathrm{~h}^{-1}$. This value appears unrealistic, since it considerably exceeds all measured ingestion rates, and since this would mean that Balanion could ingest 3 times its own cell volume per hour.

Apparently, the functional response of Balanion followed a different pattern. Over the range from 0.1 to $82 \times 10^{3}$ Cryptomonas cells $\mathrm{ml}^{-1}$, this response could be described as a highly significant linear relationship (Eq. 8; straight solid line in Fig. 2) between $(I)$ and $(N)$ with $a=-0.11 \pm 0.15$ (SE), $b=0.084 \pm 0.004$ (SE) and the correlation coefficient $\mathrm{r}=0.94(\mathrm{n}=54 ; \mathrm{p}<0.0001)$. Our data suggest for Balanion a maximum ingestion rate of 6 to 8 Cryptomonas cells ciliate ${ }^{-1} \mathrm{~h}^{-1}$.

\section{Histiobalantium bodamicum}

The growth response of Histiobalantium (Fig. 3, Table 1 \& 2) followed Eq. (6). Histiobalantium had the lowest maximum growth rate and highest threshold concentration of the species under investigation.

The ingestion rates of this species linearly increased over the range of tested prey concentrations; a nonlimiting food level for ingestion was not reached in our experiment (Fig. 3). We found a highly significant linear relationship (Eq. 8; straight solid line in Fig. 3) between $(I)$ and $(N)$ with $a=-0.3 \pm 0.3(\mathrm{SE}), b=0.11 \pm$ 0.01 (SE), the correlation coefficient $r=0.88(n=27$; $\mathrm{p}<0.0001$ ). Attempts to fit the data to the MichaelisMenten model (Eq. 7) resulted in a curve (dotted line in Fig. 3) which was almost identical to the linear

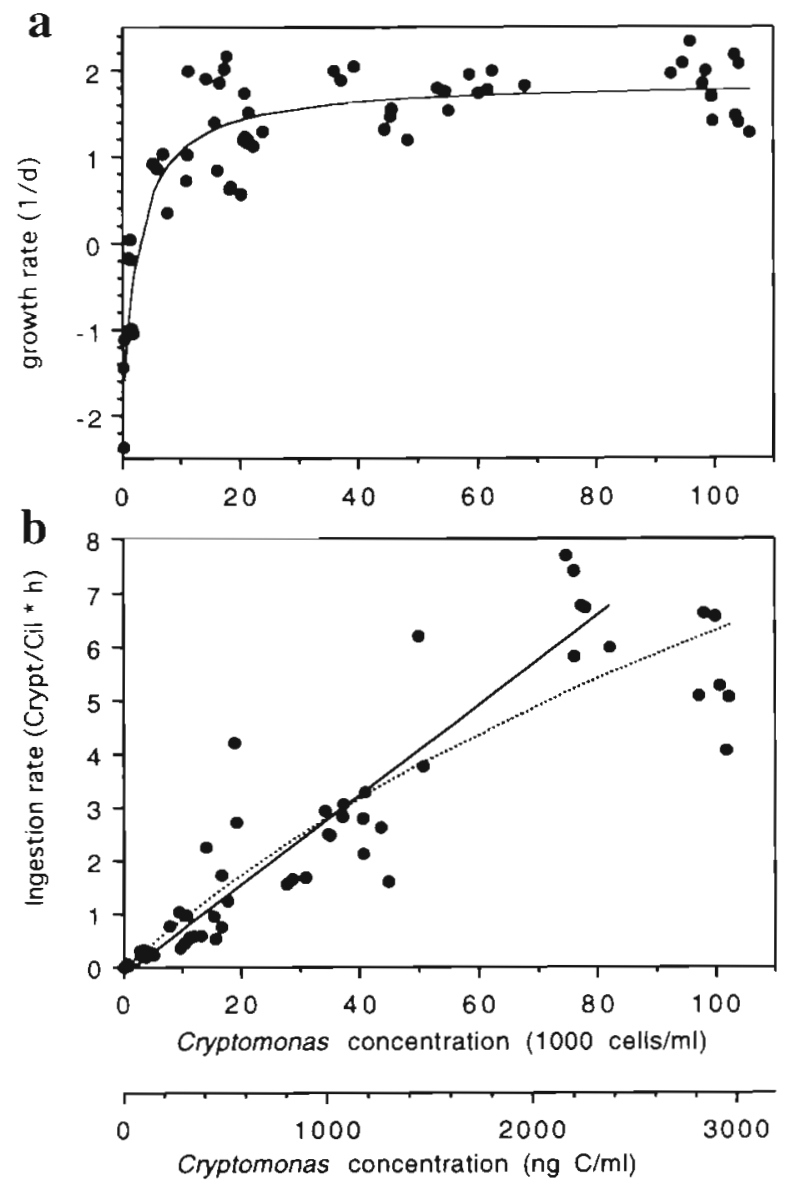

Fig. 2. Balanion planctonicum. (a) Numerical response. Observed growth rates (-) and curve fit according to Eq. (6) (solid line). (b) Functional response. Observed ingestion rates (-) and curve fit according to Eq. (7) (dotted line) and linear regression (solid line). Ingestion rates measured at Cryptomonas concentrations $>82 \times 10^{3}$ cells $\mathrm{ml}^{-1}$ were excluded from the linear regression

regression line. The present data do not allow an estimate of the maximum ingestion rate of Histiobalantium.

\section{Synopsis}

The numerical responses of all 3 ciliates followed the modified Michaelis-Menten model according to Eq. (6), with species specific values of maximum growth rates and threshold concentrations. The functional response of Strobilidium could be described by the MichaelisMenten model according to Eq. (7). In contrast, linear relationships between ingestion rate and food concentration were observed for Balanion and Histiobalantium. For all 3 species, growth rates reached a maximum earlier than ingestion rates. There were no threshold concentrations for zero ingestion. 

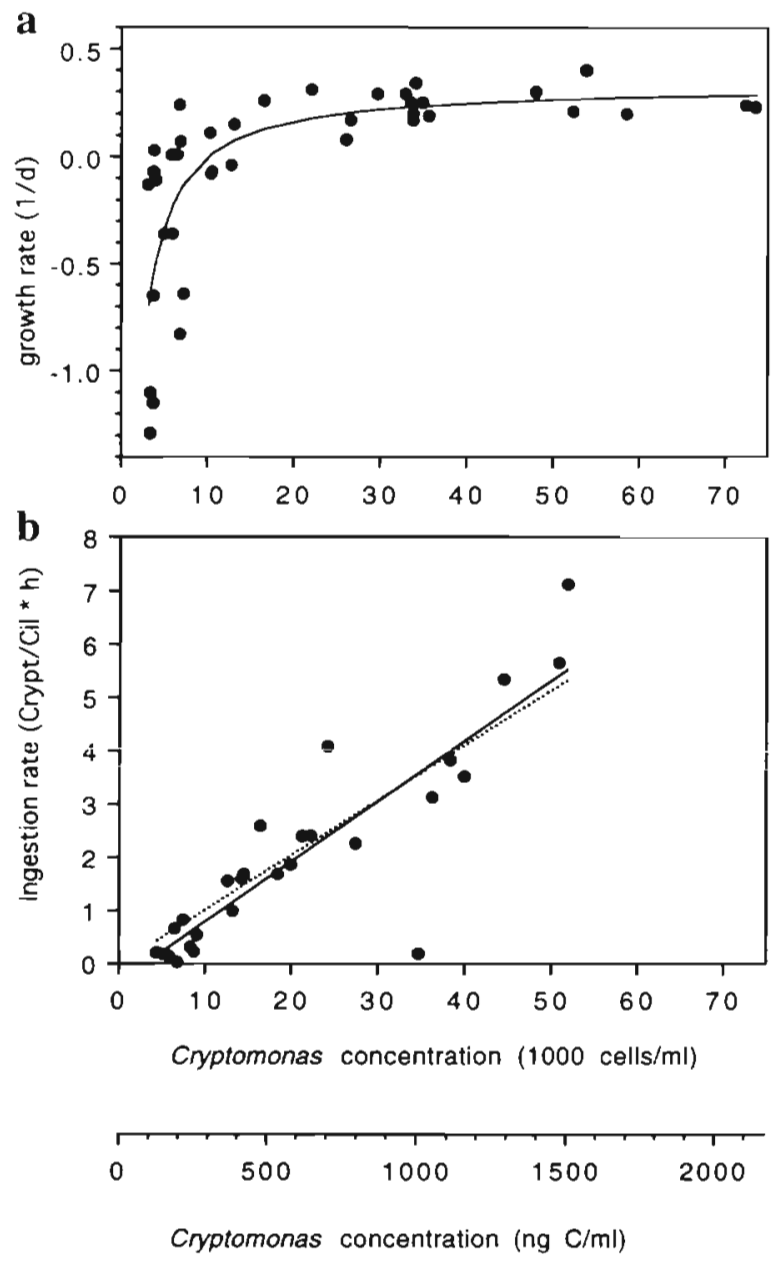

Fig. 3. Histiobalantium bodamicum. (a) Numerical response Observed growth rates ( ) and curve fit according to Eq. (6) (solid line). (b) Functional response. Observed ingestion rates (-) and curve fit according to Eq. (7) (dotted line) and linear regression (solid line)

\section{Ability to ingest Stephanodiscus}

The ciliates under investigation were cultivated for several months (Strobilidium) or years (Balanion, Histiobalantium) on a diet of Cryptomonas. In contrast, all attempts to maintain these cultures with Stephanodis-

Table 3. Qualitative test for the abilitiy to ingest Stephanodiscus hantzschii: number of individuals found with ingested diatoms ( $\mathrm{n}$-ingested) after incubation with a dense suspension of Stephanodiscus for $2 \mathrm{~h}$ (see text)

\begin{tabular}{|lrcc|}
\hline Species & $\mathrm{n}$ & $\mathrm{n}$-ingested & \% Ingestion \\
\hline Strobilidium & 68 & 58 & 82 \\
Balanion & 121 & 52 & 43 \\
Histiobalantium & 71 & 1 & 1 \\
\hline
\end{tabular}

cus as the only food source failed. Nevertheless, the ciliates might be able to utilize these small diatoms as an additional food.

To test their ability to ingest Stephanodiscus, the ciliates were incubated with a dense suspension of this prey for $2 \mathrm{~h}$ and subsequently examined for ingested diatoms after fixation with $\mathrm{HgCl}_{2}$ and protargol staining. As shown in Table 3, $80 \%$ of Strobilidium and $-40 \%$ of Balanion were found with ingested Stephanodiscus, whereas only 1 specimen of Histiobalantium with 1 ingested diatom could be detected. Apparently, the diffusion feeding Histiobalantium will generally not ingest this non-motile prey. To support this negative result, we examined another 20 live specimens of Histiobalantium after incubation with Stephanodiscus and found they had not ingested any diatoms. Consequently, we excluded Histiobalantium from further experiments with a mixed diet of Cryptomonas and Stephanodiscus.

\section{Selective feeding on Cryptomonas and Stephanodiscus}

As examples, the dynamics of experiments S1 (with Strobilidium) and B3 (with Balanion) are shown in Figs. 4 \& 5. Abundances of both ciliates increased in experimental bottles (a) and controls (b) until Cryp-

Table 4. Growth rates $\mu\left(\mathrm{d}^{-1}\right)$ of Strobilidium lacustris and Balanion planctonicum during selective feeding experiments. Mean values of $2(\mathrm{~S} 1, \mathrm{~S} 2)$ or 3 (S3, B1 to B4) parallel cultures

\begin{tabular}{|c|c|c|c|}
\hline Expt & $\begin{array}{l}\text { Time } \\
\text { interval }(\mathrm{h})\end{array}$ & $\begin{array}{c}\mu \text { with } \\
\text { Cryptomonas }\end{array}$ & $\begin{array}{l}\mu \text { with Cryptomonas } \\
\text { and Stephanodiscus }\end{array}$ \\
\hline S1 & $\begin{array}{l}18-42 \\
42-66 \\
66-91\end{array}$ & $\begin{array}{r}0.36 \\
0.04 \\
-0.35\end{array}$ & $\begin{array}{r}0.43 \\
-0.03 \\
-0.43\end{array}$ \\
\hline S2 & $\begin{array}{l}19-43 \\
43-67 \\
67-91\end{array}$ & $\begin{array}{l}- \\
- \\
-\end{array}$ & $\begin{array}{r}0.69 \\
0.37 \\
-0.24\end{array}$ \\
\hline S3 & $\begin{array}{l}19-43 \\
43-67 \\
67-91\end{array}$ & $\begin{array}{l}- \\
- \\
-\end{array}$ & $\begin{array}{l}0.79 \\
0.57 \\
0.16\end{array}$ \\
\hline B1 & $\begin{array}{l}18-42 \\
42-69 \\
69-90\end{array}$ & $\begin{array}{r}1.61 \\
0.90 \\
-1.47\end{array}$ & $\begin{array}{r}1.65 \\
1.13 \\
-0.87\end{array}$ \\
\hline B2 & $\begin{array}{l}18-42 \\
42-66 \\
66-90\end{array}$ & $\begin{array}{l}1.15 \\
1.53 \\
0.35\end{array}$ & $\begin{array}{l}0.94 \\
1.69 \\
0.62\end{array}$ \\
\hline B3 & $\begin{array}{l}11-35 \\
35-59 \\
59-83\end{array}$ & $\begin{array}{r}1.54 \\
1.77 \\
-1.30\end{array}$ & $\begin{array}{r}1.80 \\
1.76 \\
-1.16\end{array}$ \\
\hline B4 & $\begin{array}{l}18-42 \\
42-66 \\
66-90\end{array}$ & $\begin{array}{r}1.79 \\
-0.69 \\
-4.31\end{array}$ & $\begin{array}{r}1.87 \\
0.16 \\
-3.68\end{array}$ \\
\hline
\end{tabular}


Fig. 4. Changes in cell concentrations during the selective feeding experiment S1 with Strobilidium lacustris. Left: Controls (b) and (d). Right: Experimental bottles (a) and controls (c). Mean values and standard deviation of 2 replicates. Solid symbols: bottles with ciliates $(a, c)$; open symbols: controls without ciliates $(\mathrm{b}, \mathrm{d})$ : circles: ciliates; triangles: cryptophytes; squares: diatoms
Selective feeding of Strobilidium lacustris

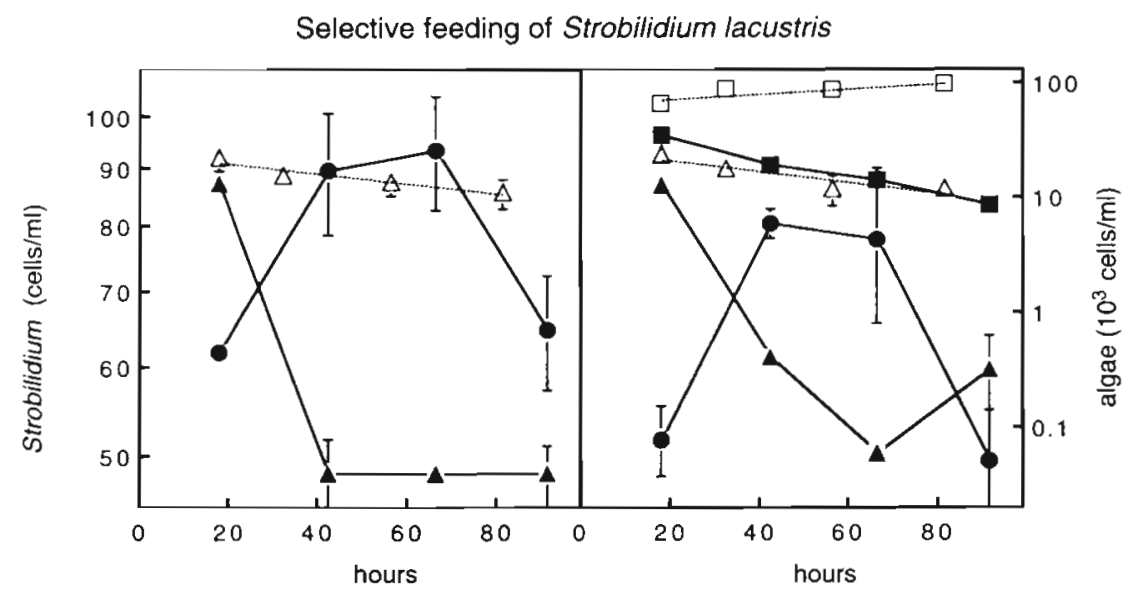

Selective feeding of Balanion planctonicum

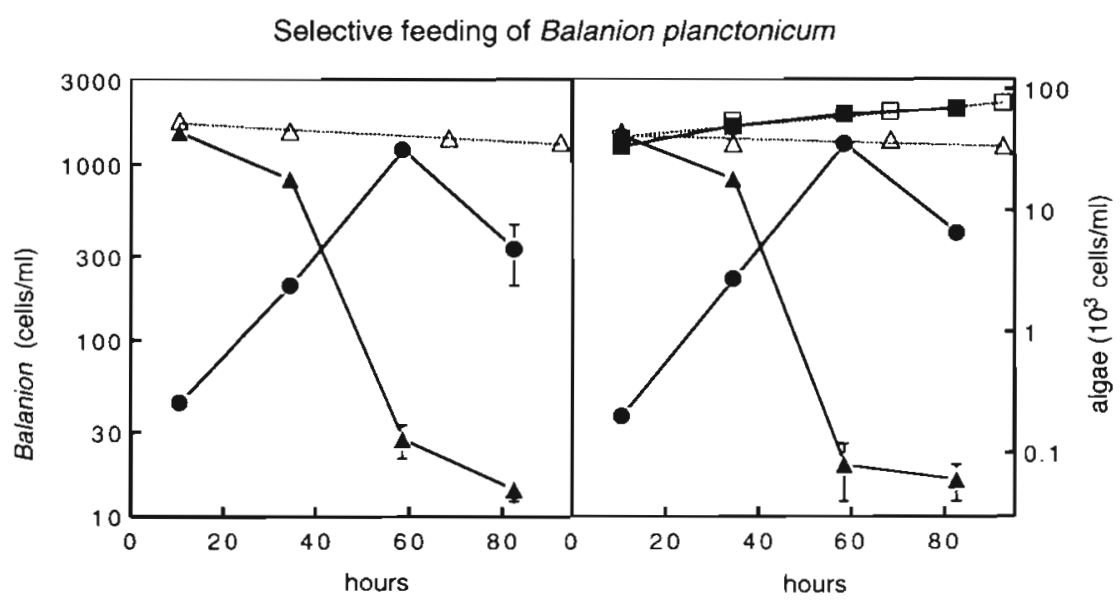

Fig. 5. Changes in cell concentrations during the selective feeding experiment B3 with Balanion planctonicum. Left: Mean values and standard deviation of 3 replicates of controls (b), single values from control (d). Right: Mean values and standard deviation of 3 replicates of experimental bottles (a), single values from control (c). Symbols as in Fig. 4 tomonas had been depleted to very low concentrations; subsequently ciliate numbers declined. A slight reduction of Stephanodiscus was observed in the cultures with Strobilidium, but not in those with Balanion.

Ciliate growth rates from the entire series are listed in Table 4 . The negative values of $\mu$ measured during the 3 rd interval of most experiments indicate that
Stephanodiscus did not support ciliate growth, though at the beginning of this interval diatom concentrations exceeded $12 \times 10^{3}$ cells $\mathrm{ml}^{-1}\left(\sim 167 \mathrm{ng} \mathrm{C} \mathrm{ml}^{-1}\right)$ in S1 to $\mathrm{S} 3$ and $6 \times 10^{4}$ cells $\mathrm{ml}^{-1}\left(\sim 834 \mathrm{ng} \mathrm{C} \mathrm{m}^{-1}\right)$ in $\mathrm{B} 1$ to $\mathrm{B} 4$. Positive growth rates at the end of experiments S 3 and B2 may be explained by higher concentrations of Cryptomonas in these cultures (cf. Table 5). Neverthe-

Table 5. Results of selective feeding experiments with Strobilidium lacustris and Balanion planctonicum in experimental bottles (a) and controls (c) (second time interval). $N$ (cells $\mathrm{ml}^{-1}$ ) $=$ mean cell numbers of ciliates and algae (Eq. 2); $\mu$ and $\mu$-con $\left(\mathrm{d}^{-1}\right)=$ growth/mortality rates of algae in experiments and controls, respectively (Eq. 1$) ; g\left(\mathrm{~d}^{-1}\right)=$ grazing loss rates (Eq. 3); $I$ (cells ind. ${ }^{-1}$ $\left.\mathrm{h}^{-1}\right)=$ ingestion rate (Eq. 4$) ; F\left(\mathrm{nl}\right.$ ind.$\left.^{-1} \mathrm{~h}^{-1}\right)=$ clearance rate (Eq. 5)

\begin{tabular}{|c|c|c|c|c|c|c|c|c|c|c|c|c|c|}
\hline \multirow{2}{*}{$\begin{array}{l}\text { Expt } \\
\text { and time } \\
\text { interval (h) }\end{array}$} & \multirow{2}{*}{$\begin{array}{c}\text { Ciliates } \\
\text { N }\end{array}$} & \multicolumn{6}{|c|}{-Cryptomonas. } & \multicolumn{6}{|c|}{-Stephanodiscus - } \\
\hline & & $N$ & $\mu$ & $\mu$-con & $g$ & $I$ & $F$ & $N$ & $\mu$ & $\mu-\operatorname{con}$ & $g$ & $I$ & $F$ \\
\hline $\mathrm{S} 1 \quad 43-67$ & 79 & 180 & -1.92 & -0.26 & 1.66 & 0.2 & 876 & 16500 & -0.31 & 0.12 & 0.43 & 3.7 & 225 \\
\hline S2 $44-68$ & 41 & 710 & -2.40 & -0.34 & 2.06 & 1.5 & 2094 & 17700 & -0.81 & 0.22 & 1.03 & 18.4 & 1043 \\
\hline S3 $44-68$ & 65 & 6380 & -2.07 & -0.13 & 1.94 & 8.0 & 1251 & 36000 & -0.50 & 0.14 & 0.64 & 14.8 & 411 \\
\hline B1 $42-69$ & 127 & 1660 & -3.25 & -1.05 & 2.20 & 1.2 & 720 & 64300 & 0.03 & 0.21 & 0.18 & 3.7 & 58 \\
\hline B2 $42-66$ & 102 & 6990 & -1.76 & -0.83 & 0.93 & 2.7 & 382 & 65100 & 0.21 & 0.18 & -0.03 & -0.8 & -12 \\
\hline B3 $35-59$ & 611 & 3340 & -5.43 & -0.06 & 5.37 & 1.2 & 366 & 56000 & 0.23 & 0.18 & -0.05 & -0.2 & -3 \\
\hline B4 $42-66$ & 343 & 3040 & -1.77 & -0.28 & 1.49 & 0.5 & 181 & 63100 & 0.27 & 0.14 & -0.13 & -1.0 & -16 \\
\hline
\end{tabular}


less, a paired $t$-test using all data of experiments B1 to B4 revealed that growth rates of Balanion in the presence of Stephanodiscus were slightly higher than in bottles without diatoms $(n=12 ; p<0.05)$.

In controls (c), growth rates of Stephanodiscus ranged from 0.12 to $0.22 \mathrm{~d}^{-1}$, whereas negative values from -0.06 to $-1.05 \mathrm{~d}^{-1}$ were found for Cryptomonas. This indicates that Cryptomonas was negatively affected by the experimental conditions such as dim light and rotation. For unknown reasons, this negative reaction was variable between experiments, with the consequence that values of $\mu_{\text {control }}$ (Eq. 3), which are needed to estimate ingestion and clearance rates, were not reliable. Therefore, we restricted these estimates to the second time interval of each experiment, when the ciliates were most numerous and had the strongest grazing impact, such that an incorrect value of $\mu_{\text {control }}$ would least affect the resulting values of $I$ and $F$.

Ingestion and clearance rates as calculated according to Eqs. (4) \& (5) are listed in Table 5. Ingestion of Cryptomonas by Strobilidium corresponded well to the functional response curve shown in Fig. 1. The oligotrich ciliate ingested Stephanodiscus at rates from 4 to 18 cells ciliate $\mathrm{h}^{-1}$. Clearance rates for the cryptophytes exceeded those for the diatoms by a factor of 2 to 4 .

Balanion ingested Cryptomonas at somewhat higher rates than expected from Fig. 2. Its consumption of Stephanodiscus could be measured only in 1 experiment (B1), with a rate of $\sim 4$ diatoms ciliate $\mathrm{C}^{-1} \mathrm{~h}^{-1}$ and a clearance rate which was 10 -fold lower than that for the cryptophytes. Expts B2 to B4 yielded negative values for $I$ and $F$ (see 'Discussion'). Obviously, the grazing impact of Balanion on the diatoms in these experiments was too small to be detected.

The results of the selective feeding experiments are summarized in Table 6. Positive selection for Cryptomonas was evident in all experiments, but differed in strength among both ciliate species.

\section{DISCUSSION}

\section{Methodological considerations}

All our experiments were performed in batch cultures, with the disadvantage that prey concentrations changed largely within sampling intervals. For analysis of functional responses, we related ingestion rates $(I)$ to mean algal concentrations $(N)$ as estimated according to Eq. (2). To study numerical responses, in contrast, we related growth rates $(\mu)$ to initial prey concentrations $\left(N_{0}\right)$ for the following reason: we measured changes in ciliate abundance, not biomass. Since sampling intervals in each experiment were chosen to approximately match ciliate generation times, cell divi-
Table 6 . Values of the selectivity index $D_{\mathrm{Cr}}$ for Cryptomonas, calculated from the clearance rates $[F]$ given in Table 5 (Jacobs 1.974 ; Eq. 9). Negative values of $F$ were set to zero

\begin{tabular}{|lccc|}
\hline Expt & $D_{\mathrm{Cr}}$ & Expt & $D_{\mathrm{Cr}}$ \\
\hline S1 & 0.59 & B1 & 0.85 \\
S2 & 0.33 & B2 & 1 \\
S3 & 0.50 & B3 & 1 \\
& & B4 & 1 \\
Mean & 0.47 & Mean & 0.96 \\
\hline
\end{tabular}

sions occurring within the first half of an interval would have been mainly due to food ingestion within the preceding interval. Initial prey numbers $\left(N_{0}\right)$, therefore, were considered a best estimate of the prey concentration which had caused the increase in ciliate numbers as recorded within the interval $(t)$.

Stephanodiscus hantzschii forms $\beta$-chitin threads 20 to $30 \mu \mathrm{m}$ in length, which considerably enlarge its effective diameter. As demonstrated by Verity \& Villareal (1986), ingestion of diatoms by protozoa may be hindered by formation of such threads. We examined our cultures and found that in different batches 3 to $28 \%$ of the diatoms were bearing threads, compared to 34 to $87 \%$ of the field population as observed over $6 \mathrm{wk}$ in spring 1996. We conclude that our S. hantzschii cultures were not quite representative of the field population, as they should have been more easily ingested than $S$. hantzschii in the lake.

The selective feeding experiments $B 2$ to $B 4$ yielded negative values of $I$ and $F$ for the diatoms. This absurd result could have been due to promotion of diatom growth by the ciliates. More likely, however, our method to determine algal concentrations was not precise enough to exactly measure the small values of $g$ for diatoms in the $B$ series. Nevertheless, our data clearly show that ingestion and clearance rates of $B a I$ anion planctonicum for Stephanodiscus hantzschi were close to zero.

\section{Numerical response}

Growth rates of all 3 species followed a curvilinear response according to the modified Michaelis-Menten model (Eq. 6). Previously determined values of $\mu_{\max }$ for Strobilidium lacustris $\left(0.99 \mathrm{~d}^{-1}\right.$ at $15.5^{\circ} \mathrm{C}$, Müller \& Geller 1993) and Histiobalantium bodamicum $\left(0.33 \mathrm{~d}^{-1}\right.$ at $18^{\circ} \mathrm{C}$, Müller \& Weisse 1994 ) agree well with our present data. Despite its large cell volume, the oligotrich ciliate $S$. lacustris can grow much faster than the smaller scuticociliate $H$. bodamicum.

Surprisingly, we found a much higher maximum growth rate for Balanion planctonicum compared to 
the value of $1.24 \mathrm{~d}^{-1}\left(15.5^{\circ} \mathrm{C}\right)$ obtained by Müler (1991) with the same cryptophyte prey. This may be explained by the fact that we studied a different strain of $B$. planctonicum, which was isolated from the lake in spring 1993 and had been adapted to the culture conditions for more than 3 yr before our experiments started. The value of $\mu_{\max }$ for $B$. planctonicum as shown in Table 1 is very close to the theoretical value of $1.86 \mathrm{~d}^{-1}$ as predicted by the model equation of Müller \& Geller (1993) for $15^{\circ} \mathrm{C}$ and a cell volume of $1800 \mu^{3}$. The closely related marine species $B$. comatum, which is of similar cell size, according to Jakobsen \& Hansen (1997) has a maximum growth rate of $1.39 \mathrm{~d}^{-1}$.

In the literature, threshold concentrations for zero growth of planktonic ciliates from 6 to $325 \mathrm{ng} \mathrm{C} \mathrm{ml}{ }^{-1}$ are reported, as reviewed by Montagnes (1996) and Jakobsen \& Hansen (1997). The values found in the present study are well within this range. Threshold concentrations of Strobilidium lacustris and Balanion planctonicum were 61 and $78 \mathrm{ng} \mathrm{C} \mathrm{ml}^{-1}$, respectively. In Lake Constance, averaged over the upper $8 \mathrm{~m}$ of the water column, similar or higher concentrations of small algae have only been recorded during phytoplankton spring blooms, whereas levels $<40 \mathrm{ng} \mathrm{C} \mathrm{ml}^{-1}$ were observed over the rest of the year (Müller et al. 1991). Accordingly, maximum abundance of $S$. lacustris and $B$. planctonicum is regularly observed in spring. However, both species are also present during the entire summer/autumn period and low numbers of $B$. planctonicum even persist during the winter months (Müller 1991, Müller et al. 1991). These findings support the hypothesis of Montagnes (1996) that, in order to to survive, planktonic ciliates must exploit small scale vertical food patches. Such patches will support growth of planktonic ciliates even when mean prey levels averaged over several meters in depth are below their threshold concentrations.

Histiobalantium bodamicum is different from the first 2 species with respect to its low maximum growth rate, its high threshold concentration and its seasonal distribution. As reported by Müller \& Weisse (1994), $H$. bodamicum occurs in Lake Constance throughout the year, with maximum development in late summer and autumn. These authors suggested that, during phytoplankton spring blooms, this species might be outcompeted by fast growing algivorous ciliates such as Balanion planctonicum and Strobilidium lacustris. Our present data support this explanation of the weak performance of $H$. bodamicum in spring. Müller \& Weisse (1994) also suggested that this scuticociliate might be a superior competitor at low levels of algal food. The high threshold concentration found in the present study disagrees with this idea.

At present, we cannot explain the success of Histiobalantium bodamicum in summer and autumn, when concentrations of small algae are low. The food spectrum of this scuticociliate needs to be studied in more detail. In the laboratory, we could maintain $H$. bodamicum on a sole diet of cryptophytes for several years. In contrast, heterotrophic flagellates $<5 \mu \mathrm{m}$, which were present in our experiments at concentrations from 4 to $16 \times 10^{4}$ cells $\mathrm{ml}^{-1}$, did not sustain survival of the population. In the lake, the diffusion feeding $H$. bodamicum might capture a wide variety of relatively large autoand heterotrophic prey.

\section{Functional response}

Different patterns of functional responses of planktonic suspension feeders are known, which represent different feeding strategies. In the context of the present study, we will discuss the rectilinear or Blackman model and the curvilinear or Michaelis-Menten model, which correspond to the Holling's (1959) type 1 and 2 functional responses and are regarded typical for feeding activities with short or long handling times of prey, respectively. Rothhaupt (1990) demonstrated that functional response patterns of rotifers of the genus Brachionus depended on food particle size. The rectilinear model was appropriate for small food particles, whereas the curvilinear model fitted best when prey items were relatively large, such that handling times interfered with the feeding process.

Functional response patterns observed in the present study were strikingly different between species. Ingestion rates of Strobilidium lacustris could be described well by the Michaelis-Menten equation. In contrast, ingestion rates of Balanion planctonicum increased linearly to a maximum level, then declined, while ingestion rates of Histiobalantium bodamicum increased linearly over the entire range of tested prey concentrations. While these linear regression lines can be interpreted as the lower regions of MichaelisMenten curves, they could also indicate a rectilinear response. Due to considerable scatter of data, as well as lack of measurements for $H$. bodamicum at saturating food concentrations, we do not have strict evidence for either a rectilinear or a curvilinear response of these ciliates. We also lack data on prey handling times which would enable the choice of the appropriate model. Different from the Brachionus study (Rothhaupt 1990), in which all predators were filter feeders, handling times of our ciliates likely depended on both feeding mode and predator:prey size.

Jakobsen \& Hansen (1997), who studied functional responses of the marine ciliate Balanion comatum and the dinoflagellate Gymnodinium sp., decided to fit measured ingestion rates of the ciliate to the curvilinear and of the dinoflagellate to the rectilinear model, 
since ' $B$. comatum ingested about 22 cells before it divided' while 'Gymnodinium sp. engulfed only about a single prey prior to cell division'.

We found no threshold concentrations for zero ingestion, which indicates that under natural conditions these ciliates will continue to feed even when prey levels become very low. For the species under investigation, formation of resting stages as a strategy to survive periods of starvation have not been observed.

In all 3 species, ingestion rates continued to increase over a wide range of food concentrations above the level required for maximum growth. Two possible explanations exist for this result: (1) ciliate cell volumes increased with increasing food concentrations, such that volume-specific growth rates reached higher values than those measured by cell counts, (2) the gross growth efficiency (GGE) decreased at high food concentrations due to incomplete digestion. This effect of 'superfluous feeding' has been observed in severa! protozoans and metazoans, as reviewed by Straile (1997).

In 1 additional experiment with Strobilidium lacustris (data not shown) we measured ciliate dimensions and calculated cell volumes by approximation to prolate or oblate spheroids. These data were used to determine growth and ingestion rates in terms of biovolume and to calculate GGE as the ratio of produced ciliate biovolume:ingested algal biovolume. Cell volumes of $S$. lacustris varied $\sim 3$-fold in starved and wellfed specimens. Volume-specific GGE ranged from 18 to $71 \%$ at high food levels ( 800 to $1200 \mathrm{ng} \mathrm{C} \mathrm{ml}^{-1}$ ), and from 50 to $168 \%$ at low food levels ( 7 to $240 \mathrm{ng} \mathrm{C} \mathrm{ml}^{-1}$ ). These rather strange results demonstrate the inadequacy to determine GGE on the basis of volume instead of carbon measurements (Ohman \& Snyder 1991, Straile 1997). Nevertheless, they indicate that the dependency of both cell volume and GGE on food concentration could be responsible for the differences between the numerical and functional response curves in our study.

\section{Selective feeding}

The nhserved responses of the ciliates to Stephanodiscus hantzschii were characteristic of their feeding mode (Fenchel 1987). Histiobalantium bodamicum apparently was not able to ingest $S$. hantzschii, since for food capture it must rely on prey motility. Balanion planctonicum and Strobilidium lacustris both selected against this seemingly unattractive food. For S. lacustris, the selectivity index $D_{\mathrm{Cr}}$ (Jacobs 1974) was in the range from 0.3 to 0.6 . While this result could be due to active selection by this filter feeding ciliate, it might also be explained by differences in encounter proba- bility with the larger motile cryptophytes and the smaller, non-motile diatoms. The $D_{\mathrm{Cr}}$ value for $B$. planctonicum, in contrast, was close to 1 , which points to active selection for Cryptomonas sp. by this raptorial feeding prostome ciliate. In short, our data suggest that the diffusion feeder could not ingest the diatoms, the raptorial feeder did not want them and the filter feeder could not avoid them.

Negative selection for Stephanodiscus hantzschii has also been observed in a field experiment in Lake Constance as reported by Weisse \& Müller (1998): during a $24 \mathrm{~h}$ in situ incubation in diffusion chambers $(28$ to 30 April 1992), a mixed community of algivorous protozoa, mainly Balanion planctonicum, strombidiid and strobilidiid ciliates and the dinoflagellate Gymnodinium helveticum, preferrentially ingested the cryptophytes Rhodomonas minuta and $R$. lens, thus causing a significant shift in phytoplankton community composition

\section{Food value of diatoms}

Our data indicate that the food value of Stephanodiscus hantzschii for both ciliates was low. While the mortality of Balanion planctonicum at high diatom concentrations can be explained by its very low ingestion rates, it is remarkable that Strobilidium lacustris, though ingesting a considerable quantity of diatoms, could also not survive on this diet. We further tested other algivorous ciliates from Lake Constance, namely Urotricha furcata, Askenasia volvox, Strobilidium humile and Pelagostrombidium fallax (Müller \& Schlegel unpubl.). All mentioned species were capable of ingesting $S$. hantzschii. In field samples, especially S. humile was frequently found with ingested diatoms. Nevertheless, none of these ciliates could be isolated and cultivated with this prey.

Literature data on utilization of diatoms by planktonic ciliates are controversial. Gifford (1985) could cultivate several marine Strombidium and Strombidinopsis strains with the dinoflagellates Heterocapsa triquetra and Scrippsiella trochoidea, but not with the diatom Thalassiosira. Verity \& Villareal (1986) demonstrated that 2 marine tintinnids could only grow on diatoms which were lacking threads. In their study, ciliate growth rates were inversely related to the effective cell size of the prey. Skogstad et al. (1987) tested 5 freshwater ciliates of the genera Cinetochilum, Bursaridium, Urotricha, Frontonia and Halteria with a wide variety of algal food. While all ciliates grew well on cryptophytes and chrysophytes, Cinetochilum was the only strain which also thrived on the diatoms $T$. pseudonana nana and Cyclotella pseudonana stelligera. Notably, Cinetochilum with a mean cell volume of 
$2300 \mu \mathrm{m}^{3}$ was the smallest of the studied ciliates. Montagnes (1996) and Montagnes et al. (1996) investigated growth responses of 5 aloricate marine oligotrichs and found that 2 species, Strombidium siculum and Strombidinopsis cheshin, grew well on the diatom $T$ pseudonana. Summarizing these data, it appears that only a few specialists among ciliates were able to utilize diatom food and that, with the exception of the tinntinnid study (Verity \& Villareal 1986), prey size was not a decisive parameter.

At present, we do not know which properties of the diatoms cause the negative reactions of many algivorous ciliates. As shown by Ban et al. (1997), these algae may also negatively affect larger herbivorous zooplankters. In a world-wide study on diatom-copepod interactions, they demonstrated that diatom diets resulted in significantly reduced egg production and egg viability of their predators. These authors suggest that an active defense mechanism of the diatoms (i.e. production of inhibitory compounds) rather than missing essential nutrients may be responsible for this negative effect.

\section{Conclusions}

Our data emphasize that numerical and functional responses of planktonic ciliates to the same cryptophyte food are species specific. The observed threshold concentrations indicate that the ciliates under investigation likely depend on small-scale food patches during the greater part of the seasonal cycle. The relationships presented in Figs. 1 to 3, therefore, do not serve to predict growth and ingestion rates from algal concentrations as averaged over large depth intervals.

The diatom Stephanodiscus hantzschii, according to our observations, is not a suitable food for the majority of algivorous ciliates in Lake Constance, though most of them can ingest these rather small cells. The properties, other than cell size, which make diatoms a low quality food for many ciliates need to be further investigated.

Acknowledgements. We wish to thank Alessandra Giani for starting the Stephanodiscus hantzschii cultures, Christine Wünsch for maintenance of algal and ciliate stock cultures and isolation of a new strain of Histiobalantium bodamicum, and Carola Kruskop for assistance with cell counts. David J. S. Montagnes and an anonymous referee offered constructive criticism on the submitted manuscript. This study was supported by the Deutsche Forschungsgemeinschaft within the Special Collaborative Program (SFB) 248 'Cycling of Matter in Lake Constance'

\section{LITERATURE CITED}

Ban S, Burns C, Castel J, Chaudron Y, Cristou E, Escribano R, Umani SF, Gasparini S, Ruis FG, Hoffmeyer M, lanora A, Kang HK, Laabir M, Lacoste A, Miralto A, Ning $X$, Poulet
S, Rodriguez V, Runge J, Shi J, Starr M, Uye SI, Wang Y (1997) The paradox of diatom-copepod interactions. Mar Ecol Prog Ser 157:287-293

Dragesco J, Iftode F (1972) Histiobalantium natans (Clap. \& Lachm. 1858): morphologie, infraciliature, morphogenèse (holotriche Hymenostomatida). Protistologica 8:347-352

Fenchel T (1986) Protozoan filter feeding. Progr Protistol 1: $65-113$

Fenchel T (1987) Ecology of Protozoa. The biology of freeliving phagotrophic protists. Science Tech, Madison, WI

Finlay BJ, Fenchel T (1996) Ecology: role of ciliates in the natural environment. In: Hausmann K, Bradbury PC (eds) Ciliates, cells as organisms. Fischer Verlag, Stuttgart, p $417-440$

Foissner W (1991) Basic light and scanning electron microscopic methods for taxonomic studies of ciliated Protozoa. Europ J Protistol 27:313-330

Foissner W (1994) Progress in taxonomy of planktonic freshwater ciliates. Mar Microb Food Webs 8:9-35

Foissner W, Skogstad A, Pratt JR (1988) Morphology and infraciliature of Trochiliopsis australis n. sp., Pelagohalteria viridis (Fromentel, 1876) n. g., n. comb., and Strobilidium lacustris n. sp. (Protozoa, Ciliophora). J Protozool 35:489-497

Foissner W, Oleksiv I, Müller H (1990) Morphology and infraciliature of some ciliates from stagnant waters (in German). Arch Protistenkol 138:191-206

Foissner W, Berger H, Kohmann F (1994) Taxonomische und ökologische Revision der Ciliaten des Saprobiensystems. Band III. Informationsberichte des Bayer Landesamtes für Wasserwirtschaft, München, 1/94

Giani A (1991) Implications of phytoplankton chemical composition for zooplankton production: experimental evidence. Oecologia 87:409-416

Gifford DJ (1985) Laboratory culture of marine planktonic oligotrichs (Ciliophora, Oligotrichida), Mar Ecol Prog Ser 23:257-267

Guillard RRI, Lorenzen CJ (1972) Yellow-green algae with chlorophyllide C. J Phycol 8:10-14

Hansen PJ, Bjornsen PK, Hansen BW (1997) Zooplankton grazing and growth: scaling within the $2-2000-\mu \mathrm{m}$ body size range. Limnol Oceanogr 42:687-704

Heinbokel JF (1978) Studies on the functional role of tintinnids in the southern California bight I. Grazing and growth rates in laboratory cultures. Mar Biol 47:177-189

Holling CS (1959) The components of predation as revealed by a study of small-mammal predation of the European pine sawfly. Can Entomol 91:293

Jacobs J (1974) Quantitative measurement of food selection. Oecologia 14:413-417

Jakobsen HH, Hansen PJ (1997) Prey size selection, grazing and growth response of the small heterotrophic dinoflagellate Gymnodinium sp. and the ciliate Balanion comatum-a comparative study. Mar Ecol Prog Ser 158: $75-86$

Krainer KH, Müller H (1995) Morphology, infraciliature and ecology of a new planktonic ciliate, Histiobalantium bodamicum n. sp. (Scuticociliatida: Histiobalantiidae). Eur J Protistol 31:389-395

Kümmerlin RE (1991) Long-term development of phytoplankton in Lake Constance. Verh Int Verein Limnol 24:826-830

Montagnes DJS (1996) Growth responses of planktonic ciliates in the genera Strobilidium and Strombidium. Mar Ecol Prog Ser 130:241-254

Montagnes DJS, Taylor FJR (1994) The salient features of five marine ciliates in the class Spirotrichea (Oligotrichia), with notes on their culturing and behaviour. J Eukaryot Microbiol 41:569-586 
Montagnes DJS, Berges JA, Harrison PJ, Taylor FJR (1994) Estimating carbon, nitrogen, protein and chlorophyll a from volume in marine phytoplankton. Limnol Oceanogr 39:1044-1060

Montagnes DJS, Berger JD, Taylor FJR (1996) Growth rate of the marine planktonic ciliate Strombidinopsis cheshiri Snyder and Ohman as a function of food concentration and interclonal variability. J Exp Mar Biol Ecol 206:121-132

Müller H (1991) Pseudobalanion planctonicum (Ciliophora, Prostomatida): ecological significance of an algivorous nanociliate in a deep meso-eutrophic lake. J Plankton Res 13:247-262

Müller H, Geller W (1993) Maximum growth rates of aquatic ciliated protozoa: the depencence on body size and temperature reconsidered. Arch Hydrobiol 126:315-327

Müller $H$, Weisse $T$ (1994) Laboratory and field observations on the scuticociliate Histiobalantium from the pelagic zone of Lake Constance, FRG. J Plankton Res 16: $391-401$

Müller $\mathrm{H}$, Schöne A, Pinto-Coelho RM, Schweizer A, Weisse $T$ (1991) Seasonal succession of ciliates in Lake Constance. Microb Ecol 21:119-138

Ohman MD, Snyder RA (1991) Growth kinetics of an omnivorous oligotrich ciliate Strombidium sp. Limnol Oceanogr 36:922-935

Petz W, Foissner W (1992) Morphology and morphogenesis of Strobilidium caudatum (Fromentel), Meseres corlissi n. sp., Halteria grandinella (Müller), and Strombidium rehwaldi $n$. sp.; and a proposed phylogenetic system for oligotrich ciliates (Protozoa, Ciliophora). J Protozool 39: $159-176$

Rothhaupt KO (1990) Changes in the functional responses of

Editorial responsibility: Karel Simek,

Ceské Budějovice, Czech Republic the rotifers Brachionus rubens and Brachionus calyciflorus with particle size. Limnol Oceanogr 35:24-32

Sherr EB, Sherr BF (1994) Bacterivory and herbivory: key roles of phagotrophic protists in pelagic food webs. Microb Ecol 28:223-235

Skogstad A, Granskog L, Klaveness D (1987) Growth of freshwater ciliates offered planktonic algae as food. J Plankton Res 9:503-512

Sommer U, Gaedke U, Schweizer A (1993) The first decade of oligotrophication of Lake Constance. II. The response of phytoplankton taxonomic composition. Oecologia 93: $276-284$

Straile D (1997) Gross growth efficiencies of protozoan and metazoan zooplankton and their dependence on food concentration, predator-prey weight ratio, and taxonomic group. Limnol Oceanogr 42:1375-1385

Verity PG, Villareal TA (1986) The relative food value of diatoms, dinoflagellates, flagellates and cyanobacteria for tintinnid ciliates. Arch Protistenkd 131:71-84

Weisse $T_{1}$ Kirchhoff B (1997) Feeding of the heterotrophic freshwater dinoflagellate Peridiniopsis berolinense on cryptophytes: analysis by flow cytometry and electronic particle counting. Aquat Microb Ecol 12:153-164

Weisse T, Müller H (1998) Planktonic protozoa and the microbial food web in Lake Constance. In: Gaedke U, Bäuerle E (eds) Lake Constance, characterization of an ecosystem in transition. Arch Hydrobiol Special Issues, Adv Limnol 53: $223-254$

Weisse T, Müller H, Pinto-Coelho $R$, Schweitzer A, Springmann D, Baldringer $G$ (1990) Response of the microbial loop to the phytoplankton spring bloom in a large prealpine lake. Limnol Oceanogr 35:781-794

Submitted: February 2, 1998; Accepted: August 28, 1998

Proofs received from author(s): April 13, 1999 